\title{
The Importance of Computerized Analysis on Spoilage of Plantain (Musa paradisiacal), Before Harvest and Carriage to Market, in Nigeria
}

\author{
Prince Awojoodu Soji \\ Department of Computer Science and Mathematics, Oduduwa University, Ile-Ife Kingdom, Nigeria
}

Email address:

awojoodusoji@yahoo.com

\section{To cite this article:}

Prince Awojoodu Soji. The Importance of Computerized Analysis on Spoilage of Plantain (Musa paradisiacal), Before Harvest and Carriage to Market, in Nigeria. American Journal of Plant Biology. Vol. 5, No. 1, 2020, pp. 1-10. doi: 10.11648/j.ajpb.20200501.11

Received: September 11, 2019; Accepted: November 4, 2019; Published: January 21, 2020

\begin{abstract}
This research work, was carried out, to find the importance of computerized analysis on spoilage of plantain, before harvest and carriage to market in Osun State, Nigeria. 3,600 open questionnaires were distributed to the 4 Local Governments, namely: (Ife East, Ife South, Ife Central, and Ife North), local government areas in Osun State, Nigeria. Out of which 900 was used for farmers, in each local government. A total of 36 locations were sampled in all the four local governments, out of which 100 questionnaires were used in each location. It was gathered that above $70 \%$ of the farmers supported, the importance of computerized analysis on spoilage of plantain, before harvest and carriage to market in Osun State, Nigeria, while less than $30 \%$ of the people could not even understand whether there was the needy, on the importance of computerized analysis on spoilage of plantain, before harvest and carriage to market in Osun State, Nigeria, or not. The results from the questionnaires when using Pearson one-tailed correlation coefficient, however revealed that there was no significant difference from all the farmers visited and sampled, $(\mathrm{p}<0.05)$, table 5. This shows a strong positive correlation, which implying that, the importance of computerized analysis on spoilage of plantain, before harvest and carriage to market in Osun State, Nigeria, was strongly influenced and enhanced farmer's support, and had therefore, made this research work to become a reality, $(\mathrm{p}<0.05)$, table 5. The reasons may be due to the fact that in Nigeria, as one of the major staple food, plantain products is not only commonly used for making DODO (fried ripe pulp), IPEKERE well known as chip (fried un-ripped pulp), and as plantain flour but there is a great potential for the processing of plantain. It could however be processed to food / foodstuffs, such as breakfast cereals, baby food (soy-musa), flour, chips and snacks food. Also, industrial product of plantain processing includes: wine / beer, syrups, vinegar, biscuit, among others. Pie Chart was used to depict the summary data of each of the local government areas sampled.
\end{abstract}

Keywords: Plantain (Musa Paradisiacal), 4 Local Governments, Spoilage, Pearson One-Tailed Correlation, Harvest and Carriage

\section{Introduction}

Plantain (Musa paradisiacal), plant of the banana (qv) family (Musaceae), closely related to the common banana (M. Sapientum). It is one of the most staple foods mostly grown in the tropical regions of Nigeria, and West Arica. It is one of the food crops grown in Nigeria, and among the foremost sources of carbohydrates in humid tropical that contained $35 \% \mathrm{CHO}, 0.2$ to $0.5 \%$ fats, $1.2 \%$ protein and $0.8 \%$ ash. In terms of gross value of production, plantain is one of the most important fruit in developing world, [1].
As one of the major staple food in Nigeria, plantain products is commonly used for making DODO (fried ripe pulp), IPEKERE well known as chip (fried un-ripped pulp), and as plantain flour. Plantain flour has advantage over other starchy foods, since it contains protein, mineral, and vitamins, and medically plantain can be used to cure a lot of ailments including sore throat, tongilolitis, diarrhea vomiting, and it is said to be a major diet in the production of soymusa, which can be used in the treatment of kwashiorkor. There is a great potential for the processing of plantain. It could be processed to food / foodstuffs, such as breakfast 
cereals, baby food (soy-musa), flour, chip sand snacks food. Industrial product of plantain processing includes: wine / beer, syrups, vinegar, biscuit, among others. The plantain is at all plant (3-10meters), (10-33feet)), with a conical false "trunk" formed by the leaf sheath so fits spirally arranged leaves, which are 1.5 to $3 \mathrm{~m}$ long, and about $0.5 \mathrm{~m}$ wide, the fruit which is green, is typically larger than the common banana. The botanical classification of plantains, and bananas is so complicated that plantain is variously viewed as a subspecies of the banana, and the banana as a subspecies of plantain. In Nigeria, plantain is a special delicacy prepared by frying, boiling, steaming or made in to plantain chips. It can be processed into flour which is gradually substituting the use of wheat flour due to its superior nutritional value. Plantain is also exported from Nigeria to other countries of the world. The edible fruit of the plantain has more starch than the banana and is not eaten raw. Since plantain has a maximum of starch before it ripens, it is usually cooked green, either boiled or fried, often with coconut juice or sugar as a flavouring.

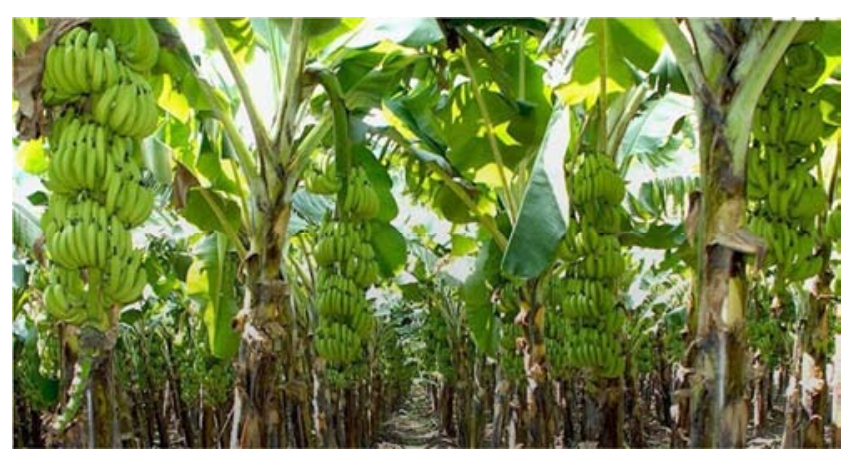

Figure 1. The most important fruit in developing world.

Plantain occupies a strategy position for rapid food production in Nigeria, among the starchy staple food, it is ranked third. The output of plantain in Nigeria had doubled in the last 29 years, despite having a production system concentrated in the hands of small scale farmers, [2]. The plantain meal can be further refined to a flour, or dried for later use in cooking or ground for use as a meal. In some parts of East Africa, the plantain is as table food and beer making crop, notably in central and eastern Uganda and Tanzania (formerly Tanganyika) particularly in the area inhabited by the Chagga people. Plantain (Musa paradisiacal), atriploid $(2 n=3 x=33)$ grant perennial herb, is a natural inter-specific hybrid between the two wild spies $M$. Acuminata, which contributed genome B., [3]. The plantain subgroup of cultivars is supposedly homogeneous group, $i$. e., it was widely derived from a very limited number of botanically different parent source. Despite botanical homogeneity, the crop greatly diversified by accumulated somatic mutations to give a complex spectrum of morphological variability, [4].

Plantain History/Origin:

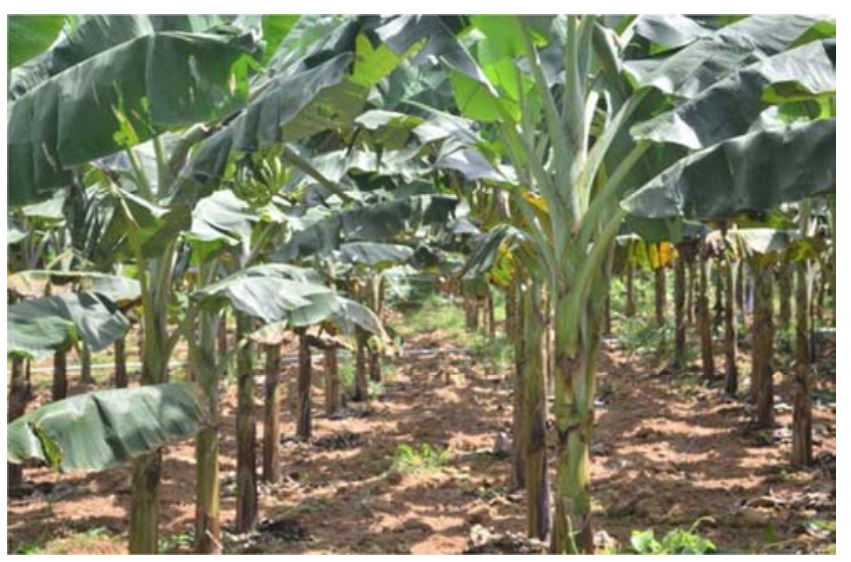

Figure 2. PlantainHistory/Origin.

The plant is believed to have originated in Southern Asia. Two groups of plantains are thought to have a common origin: the horn plantain and the French plantain. Both types grow in India, Africa, Egypt, and tropical America. The French plantains also occur in Indonesia and the Islands of the Pacific. Plantain is also a common name for plant soft hegenus plant ago (qv) of the order Scrophulariales. It is a native to Europe and parts of Asia, but was said to have been in traduced to North America when the settlers came from Europe. It's scientific name is Plantago Major. The widow array of plantain cultivars observed today, particularly in Africa, reflects along history of cultivation. Plantain cultivars were selected and cultivated by man or their edible starchy fruits.

Years of Maturity of Plantain (Musa paradisiacal), in Nigeria:

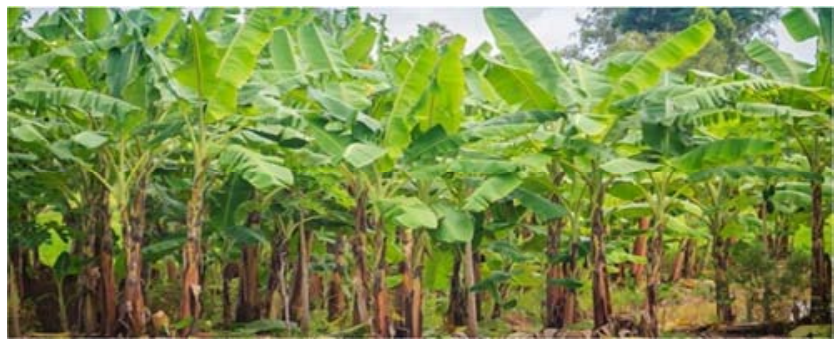

Figure 3. Plantain years of maturity.

Plantain matures very fast. In Nigeria. It is better to plant plantains in the time of raining season, around the first week in Mach. The plant should grow without stress and vigorously during the first 3 to 4 months after planting. To produce fruits, this tree needs 10 to 15 months without freezing temperatures, to produce flowers; and another 4 to 8 months for the plantain to grow. Growing a plantain tree takes special care to produce fruit, but even without fruit, this tree is very ornamental. After well grown, it became a seasonal and perishable fruits and goods for consumption both for the buyers and the people.

Plantain (Musa paradisiacal), 


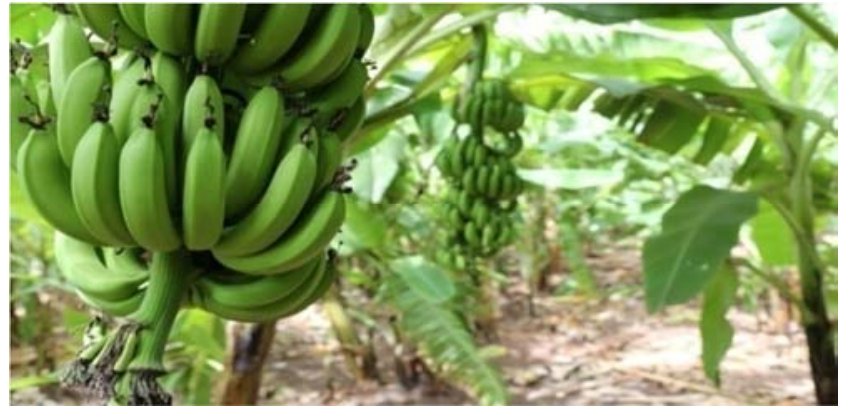

Figure 4. Plantain (Musa paradisiacal), spoilage before harvest and carriage.

To maintain high quality of plantain, for both short term and long term harvest and carriage, there are some risks involved concerning spoilage before harvesting and carrying them. This is because, in Nigeria, plantain sustainable production is threatened by increasing disease and pest pressure. One of the most critical constraints to plantain is a leaf spot disease, called black sigatoka, which is caused by the fungus my cosphaerella fijiensismorelet. All plantains germ plasm, currently maintained, and collected from west, central and East Africa, central America and the Philippines, is equally susceptible to the black sigotoka disease, [5]. The crop however, is now among the most important staple foods in the tropical humid forest ecology of Africa and America.

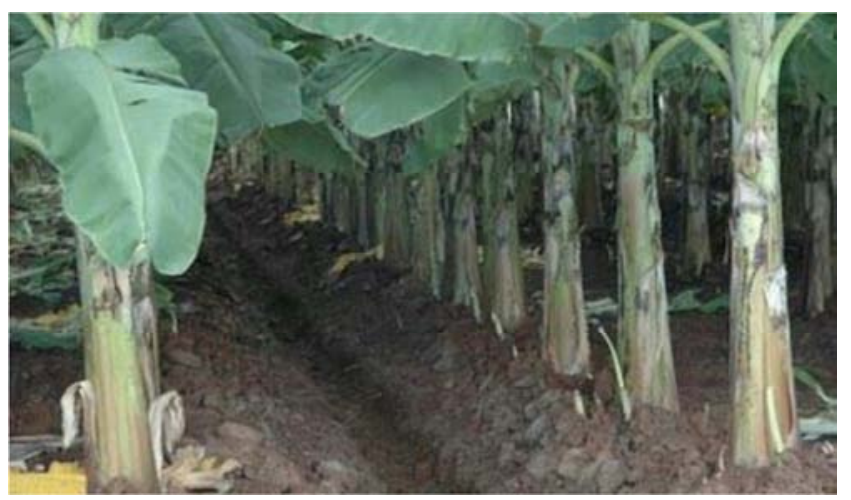

Figure 5. Plantain (Musa paradisiacal), Disease.

The disease is of rather recent introduction in Africa, where it spread rapidly through all plantain and banana producing areas during the past two decades. It results in yield losses of $30-50 \%$, [6]. Plantain has long been considered as intractable to genetic improvement due to high levels of female sterility and the triploid nature of the crop, [7]. Few cultivars were known to set seed at rates not exceeding an average of one seed at rates not exceeding an average of one seed per bunch after hand pollination, [8].

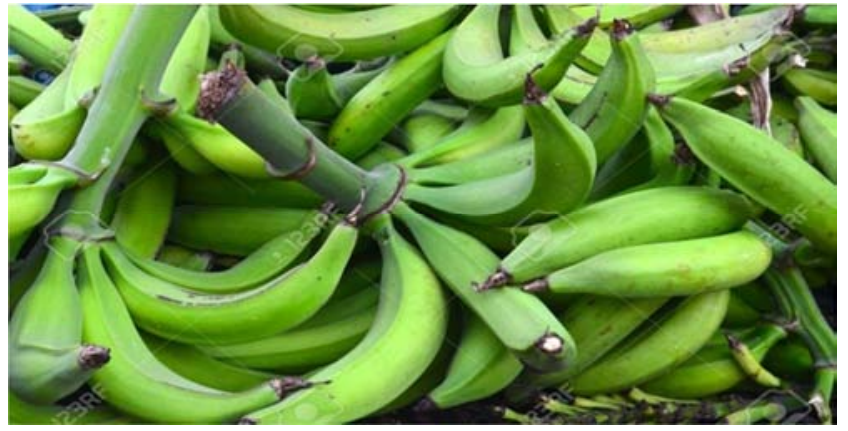

Figure 6. Plantain (Musa paradisiacal), harvest and carriage to market.

Plantain (Musa paradisiacal), Carriage to Market:

Plantains often take as long as three or four weeks to become completely ripe, while bananas go from green to ripe in 7 to 11 days, depending on temperature and other factors. The plantains market is young and not crowded. A plantain plantation farm should have the right type of soil and located in an area with favourable weather condition or the growth of plantation. In Nigeria, the major markets for this fruit are basically made up of two categories: the fresh fruits Market, (since the fresh fruits are majorly perishable and not durable). And the processed fruits Market, (where electro-mechanical devices / machines is used for changing such raw materials into finished goods for the consumers).

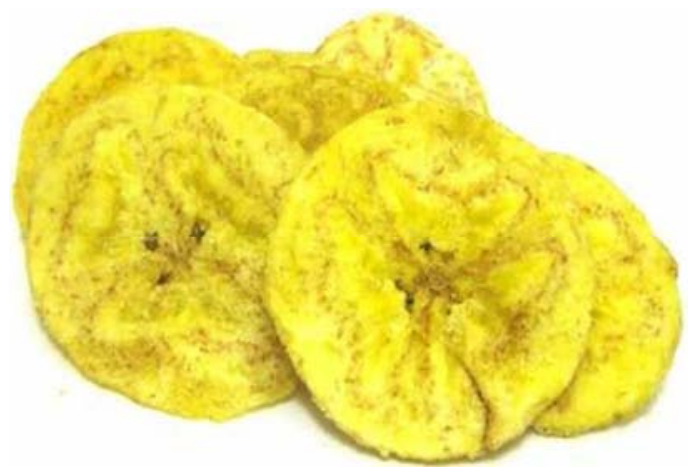

Figure 7. Plantain chip.

A growing industry mainly plantain chip, is believed to be responsible for the high demand be in experienced now in Nigeria. Today, the number of farms producing plantain in Nigeria is very few and this makes the demand for it high and profitable. The major producing States for Plantains are: Oyo, Ogun, Osun, Kogi, Bennue, Ebonyi, Kaduna, Ekiti, Imo, Edo, Delta and other states in the tropics.

\subsection{Material and Methods}

The responses of the people in different locations of the four local government areas can be seen from the decision table as below:

Table 1. The Decision Table.

\begin{tabular}{|c|c|c|c|}
\hline Sub & Above70\% & Below30\% & Open headed Questionnaires \\
\hline $\begin{array}{l}\text { The importance of computerised analysis on spoilage of plantain, before harvest and } \\
\text { carriage to market in Osun State, Nigeria. }\end{array}$ & $\mathrm{X}$ & & \\
\hline I do not know & & $X$ & \\
\hline
\end{tabular}


The below are the points ticked by the majority of the people (above $70 \%$ table 1 ), from the questionnaires who understood and supported, the importance of computerized analysis on spoilage of plantain, before harvest and carriage to market in Nigeria.

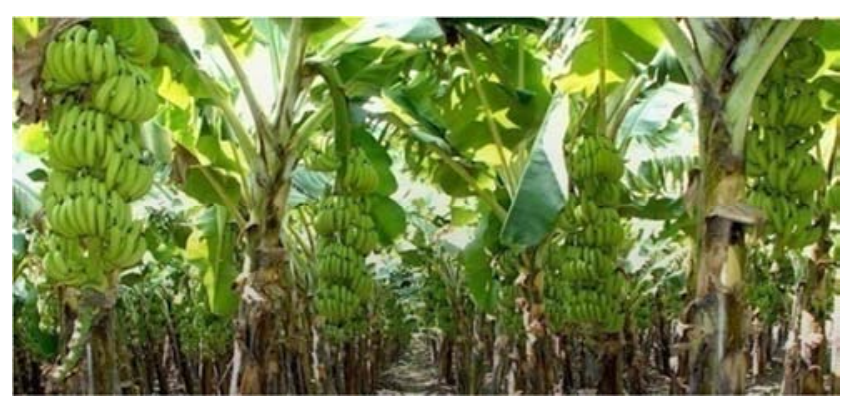

Figure 8. Plantain Importance.

[a]. Plantain is used for bladder infections, bronchitis, cold and irritated or bleeding hermorrhoids. [b]. Plantain is beneficial for over weight and obese people. [c]. It is used to kill germs and reduces welling for eye irritation. [d]. Plantain is used as a treatment for hyperlipidemia, for anticancer effects and for respiratory treatment in human. [e]. Plantain has been effective for chronic bronchitis, and cough. [f]. It cures respiratory track disorder. [g]. It aids in quicker healing of wounds: (the ingredient present in plantain leave herbs has germicidal and antibacterial properties, thus when applied to the wound, the herb helps in killing the germs). [h]. It aids treatment for acneandrosacea (from the extraction of herbal leaf). [i]. It cures blood poisoning: (the leaves can be drank as a tea). [j]. It prevents bleeding (either chew the leaves or make a paste of it to be applied typically on the bleeding zone. [k]. Plantain safeguard scardio vascular health (the herbs derived from plantain has the potential, to lower triglycerides level and keep the under required amount). [1]. Plantain is good for health. [m]. As a remedy for tuberculosis and syphilis. [n]. Plantain is good for digestive system. [o]. Plantain helps in easing dandruff: (the antiseptic and antibacterial properties of plantain herb scan shield your scalp from infections and offer relief from dandruff. [p]. It curbs insect bites. [q]. Plantain is a natural relief of sun burnt. [r]. Plantain is good for your hair. [s]. It helps in coping with post partum issues: (the herbs can be used for faster post partum recovery). [t]. It is known for potential anti-cancer properties.

\subsection{Study Area}

The study has been conducted in Osun [pronounced; "O'shoon]. Osun State is an inland State in South-Western Nigeria. Its capital is Osogbo. It has a population of 3. 4 million and of $9,251 \mathrm{~km}^{2}$ in Area. It is bounded in the North by Ekiti State and partly by Ondo State, in the South by Ogun State and in the West by Oyo State. Osun is home to several of Nigeria's most famous landmarks, including the campus of Obafemi Awolowo University; Nigeria's preeminent institution of higher learning. The university also located in the ancient town of Ile-Ife, an important early centre of political and religious development for Yoruba culture. Other important cities and towns include the ancient Kingdom-capitals of Oke-Ila Orangun, Ila-Orangun, IjebuJesa, Ede, Iwo, Ejigbo, Modakeke, Ibokun, Ode-Omu, Ifetedo, Esa-Oke, Ilesa and Igbajo.

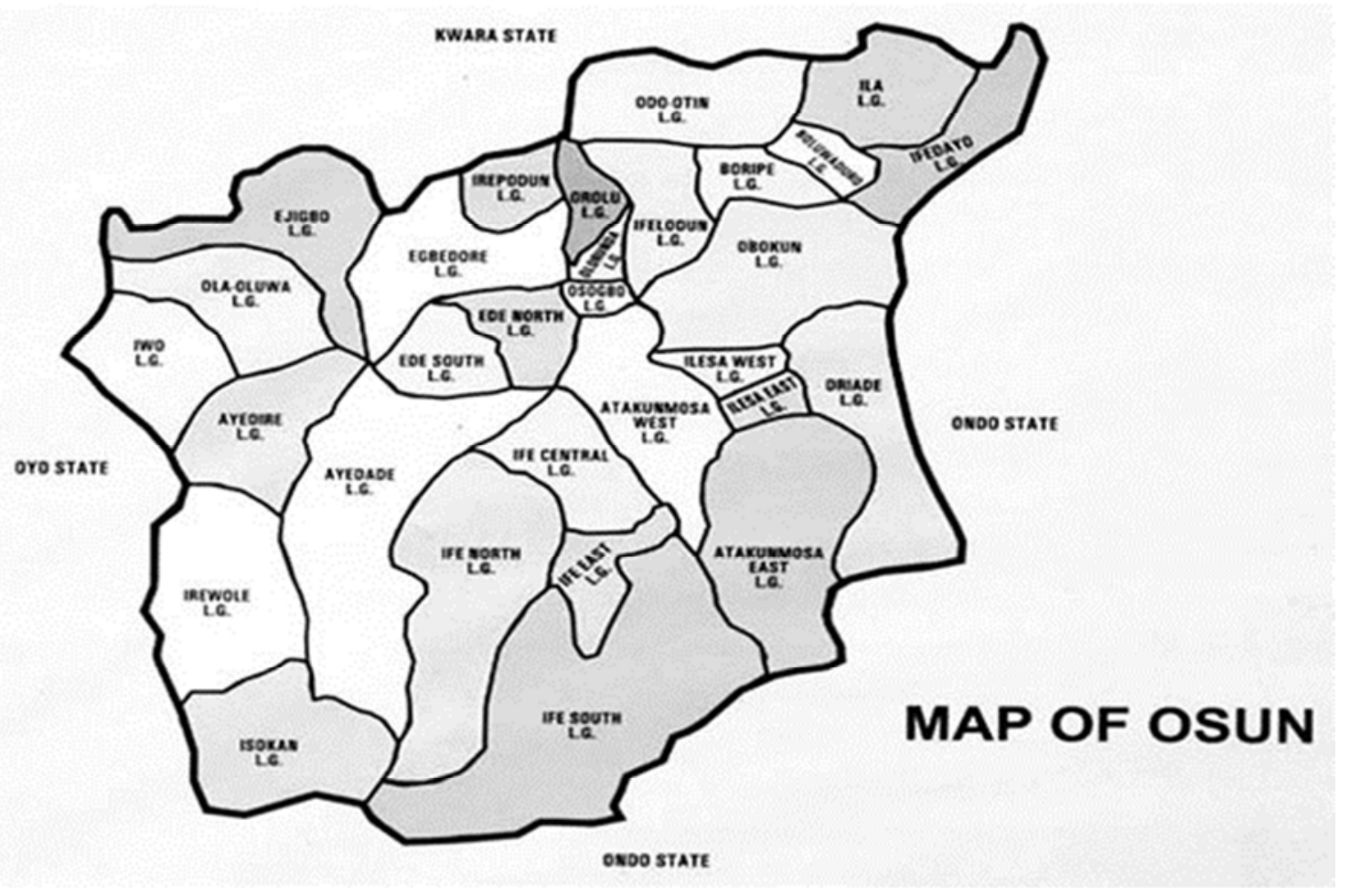

Figure 9. The Map of Osun State. 


\section{Results and Discussion}

Questionnaires were distributed to 4 Local government areas that is, (Ife East, Ife South, Ife Central and Ife North). The results from the questionnaires however revealed that, the importance of computerized analysis on spoilage of plantain, before harvest and carriage to market in Osun State, Nigeria are manifold:

There was no significant difference on the people in all the local government areas visited, $(\mathrm{p}<0.05)$.

Table 2. People's response.

\begin{tabular}{|c|c|c|c|c|}
\hline Wards & Ife East & & Ife South & \\
\hline \multirow[t]{2}{*}{ People's Response } & $\begin{array}{l}\text { The importance of computerized analysis } \\
\text { on spoil age of plantain, before harvest } \\
\text { and carriage to market in Nigeria. }\end{array}$ & I do not know & $\begin{array}{l}\text { The importance of computerized analysis } \\
\text { on spoilage of plantain, before harvest and } \\
\text { carriage to market in Nigeria. }\end{array}$ & I do not know \\
\hline & $624,69.3 \%$ & $276,30.7 \%$ & $636,70.7 \%$ & $264,29.3 \%$ \\
\hline Wards & Ife Central & & Ife North & \\
\hline \multirow[t]{2}{*}{ People's Response } & $\begin{array}{l}\text { The importance of computerized analysis } \\
\text { on spoilage of plantain, before harvest and } \\
\text { carriage to market in Nigeria. }\end{array}$ & I do not know & $\begin{array}{l}\text { The importance of computerized analysis } \\
\text { on spoilage of plantain, before harvest and } \\
\text { carriage to market in Nigeria. }\end{array}$ & I do not know \\
\hline & $633,70.3 \%$ & $267,29.7 \%$ & $629,69.9 \%$ & $27130.1 \%$ \\
\hline
\end{tabular}

From the above table 2, in Ife East, there are 624 people's response with $69.3 \%$, Ife South, 636 with $70.7 \%$, Ife Central, 633 with $70.3 \%$, and Ife North, 629 with $69.9 \%$, were those People who supported, the importance of computerized analysis on spoilage of plantain, before harvest and carriage to market in Osun State, Nigeria, while in Ife East, 276 with
$30.7 \%$, Ife South, 264 with $29.3 \%$, Ife Central, 267 with $29.7 \%$, and Ife North, 271 with $30.1 \%$ respectively, could not even know whether computerized analysis on spoilage of plantain, before harvest and carriage to market in Osun State, Nigeria was important or not.

Table 3. The different locations as (A, B, C, D, E, F, G, H and I) and the local government areas as (IFE EAST IFE SOUTH, IFECENTRAL, AND IFE NORTH respectively). Also the summary data collected, from the 4 Local Governments sampled, out of which 900 were used in each local government.

\begin{tabular}{|c|c|c|c|c|c|c|c|c|c|}
\hline \multirow[t]{2}{*}{ Local government } & \multirow{2}{*}{$\begin{array}{l}\text { Location } \\
\text { A }\end{array}$} & \multicolumn{2}{|c|}{ Ife East } & \multicolumn{2}{|c|}{ Ife South } & \multicolumn{2}{|c|}{ Ife Central } & \multicolumn{2}{|c|}{ Ife North } \\
\hline & & 71 & 29 & 68 & 32 & 75 & 25 & 68 & 32 \\
\hline \multirow{8}{*}{ Peoples Respondent } & $\mathrm{B}$ & 72 & 28 & 72 & 28 & 73 & 27 & 79 & 21 \\
\hline & $\mathrm{C}$ & 63 & 37 & 70 & 30 & 69 & 31 & 70 & 30 \\
\hline & D & 63 & 37 & 64 & 36 & 64 & 36 & 63 & 37 \\
\hline & E & 64 & 36 & 76 & 24 & 75 & 25 & 72 & 28 \\
\hline & $\mathrm{F}$ & 69 & 31 & 79 & 21 & 78 & 22 & 74 & 26 \\
\hline & G & 74 & 26 & 70 & 30 & 68 & 32 & 67 & 33 \\
\hline & $\mathrm{H}$ & 76 & 24 & 72 & 28 & 64 & 36 & 68 & 32 \\
\hline & I & 72 & 28 & 65 & 35 & 67 & 33 & 68 & 32 \\
\hline TOTAL $=$ & 9 & 624 & 276 & 636 & 264 & 633 & 267 & 629 & 271 \\
\hline Grand Total $=$ & 9 & 900 & & 900 & & 900 & & 900 & \\
\hline
\end{tabular}

Table 4. The descriptive statistics.

\begin{tabular}{llll}
\hline Descriptive Statistics & & & \\
\hline & Mean & Std. Deviation & N \\
\hline IFEEAST & 69.3333 & 4.89898 & 9 \\
IFESOUTH & 70.6667 & 4.82183 & 9 \\
IFECENTRAL & 70.3333 & 5.09902 & 9 \\
IFENORTH & 69.8889 & 4.62181 & 9 \\
\hline
\end{tabular}

\section{Correlations}

Table 5. The Pearson Correlation for the 4 local governments.

\begin{tabular}{|c|c|c|c|c|c|}
\hline \multicolumn{6}{|c|}{ Correlations } \\
\hline & & IFE EAST & IFE SOUTH & IFE CENTRAL & IFE NORTH \\
\hline \multirow{4}{*}{ Ife East } & Pearson Correlation & 1 & .026 & -.130 & .112 \\
\hline & Sig. (1-tailed) & & .473 & .369 & .387 \\
\hline & Sum of Squares and Cross-products & 192.000 & 5.000 & -26.000 & 20.333 \\
\hline & Covariance & 24.000 & .625 & -3.250 & 2.542 \\
\hline
\end{tabular}




\begin{tabular}{llllll}
\hline Correlations & & & & & \\
\hline & & IFE EAST & IFE SOUTH & IFE CENTRAL & IFE NORTH \\
\hline \multirow{5}{*}{ Ife South } & $\mathrm{N}$ & 9 & 9 & 9 & 9 \\
& Pearson Correlation & .026 & 1 & $.686^{*}$ & $.666^{*}$ \\
& Sig. (1-tailed) & .473 & & .021 & .025 \\
& Sum of Squares and Cross-products & 5.000 & 186.000 & 135.000 & 118.667 \\
& Covariance & .625 & 23.250 & 16.875 & 14.833 \\
& $\mathrm{~N}$ & 9 & 9 & 9 & 9 \\
Ife Central & Pearson Correlation & -.130 & $.686^{*}$ & 1 & $.665^{*}$ \\
& Sig. (1-tailed) & .369 & .021 & & .025 \\
& Sum of Squares and Cross-products & -26.000 & 135.000 & 208.000 & 125.333 \\
& Covariance & -3.250 & 16.875 & 26.000 & 15.667 \\
Ife North & N & 9 & 9 & 9 & 9 \\
& Pearson Correlation & .112 & $.666^{*}$ & $.665^{*}$ & .025 \\
& Sig. (1-tailed) & .387 & .025 & 125.333 \\
\end{tabular}

*. Correlationissignificantatthe 0 . 05level (1-tailed).

FREQUENCIES VARIABLES=IFEEAST IFESOUTHIFECENTRALIFENORTH.

/NTILES $=4$.

/NTILES $=10$

/STATISTICS=STDDEVVARIANCERANGEMINIMUMMAXIMUMSEMEANMEANMEDIANMODESUMSKEWNESSSESKEW.

KURTOSISSEKURT.

/GROUPED=IFEEASTIFESOUTHIFECENTRALIFENORTH.

/ORDER=ANALYSIS.

Table 6. The mean, mode, std. deviationofthe4localgovernmentareas.

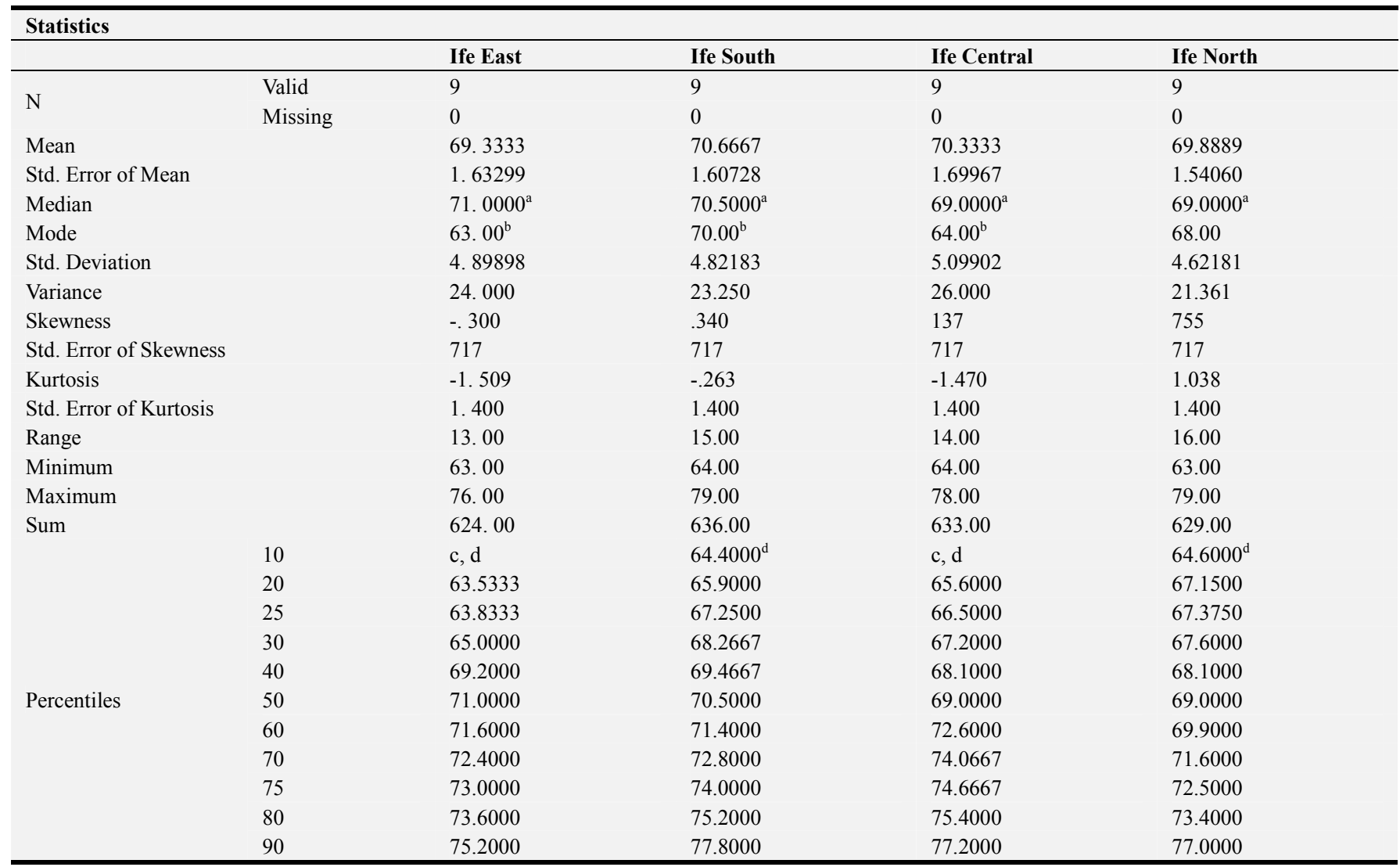

a. Calculated from grouped data.

b. Multiple modes exist. The smallest value is shown.

c. Thelowerboundofthefirstintervalortheupperboundofthelastintervalisnotknown. Some percentiles are undefined.

d. Percentiles are calculated from grouped data. 
Frequency Table

Tables (7, 8, 9, and 10). The frequency Tables for (Ife East, Ife South, Ife Central and Ife North).

Table 7. Valid and cumulative percentages of Ife East.

\begin{tabular}{|c|c|c|c|c|c|}
\hline \multicolumn{6}{|c|}{ Ife East } \\
\hline & & Frequency & Percent & Valid Percent & Cumulative Percent \\
\hline \multirow{8}{*}{ Valid } & 63.00 & 2 & 22.2 & 22.2 & 22.2 \\
\hline & 64.00 & 1 & 11.1 & 11.1 & 33.3 \\
\hline & 69.00 & 1 & 11.1 & 11.1 & 44.4 \\
\hline & 71.00 & 1 & 11.1 & 11.1 & 55.6 \\
\hline & 72.00 & 2 & 22.2 & 22.2 & 77.8 \\
\hline & 74.00 & 1 & 11.1 & 11.1 & 88.9 \\
\hline & 76.00 & 1 & 11.1 & 11.1 & 100.0 \\
\hline & Total & 9 & 100.0 & 100.0 & \\
\hline
\end{tabular}

Table 8. Valid and cumulative percentages of Ife South.

\begin{tabular}{|c|c|c|c|c|c|}
\hline \multicolumn{6}{|c|}{ Ife South } \\
\hline & & Frequency & Percent & Valid Percent & Cumulative Percent \\
\hline \multirow{8}{*}{ Valid } & 64.00 & 1 & 11.1 & 11.1 & 11.1 \\
\hline & 65.00 & 1 & 11.1 & 11.1 & 22.2 \\
\hline & 68.00 & 1 & 11.1 & 11.1 & 33.3 \\
\hline & 70.00 & 2 & 22.2 & 22.2 & 55.6 \\
\hline & 72.00 & 2 & 22.2 & 22.2 & 77.8 \\
\hline & 76.00 & 1 & 11.1 & 11.1 & 88.9 \\
\hline & 79.00 & 1 & 11.1 & 11.1 & 100.0 \\
\hline & Total & 9 & 100.0 & 100.0 & \\
\hline
\end{tabular}

Table 9. Valid and cumulative percentages of Ife Central.

\begin{tabular}{|c|c|c|c|c|c|}
\hline \multicolumn{6}{|c|}{ Ife Central } \\
\hline & & Frequency & Percent & Valid Percent & Cumulative Percent \\
\hline \multirow{8}{*}{ Valid } & 64.00 & 2 & 22.2 & 22.2 & 22.2 \\
\hline & 67.00 & 1 & 11.1 & 11.1 & 33.3 \\
\hline & 68.00 & 1 & 11.1 & 11.1 & 44.4 \\
\hline & 69.00 & 1 & 11.1 & 11.1 & 55.6 \\
\hline & 73.00 & 1 & 11.1 & 11.1 & 66.7 \\
\hline & 75.00 & 2 & 22.2 & 22.2 & 88.9 \\
\hline & 78.00 & 1 & 11.1 & 11.1 & 100.0 \\
\hline & Total & 9 & 100.0 & 100.0 & \\
\hline
\end{tabular}

Table 10. Valid and cumulative percentages of Ife North.

\begin{tabular}{|c|c|c|c|c|c|}
\hline \multicolumn{6}{|c|}{ Ife North } \\
\hline & & Frequency & Percent & Valid Percent & Cumulative Percent \\
\hline \multirow{8}{*}{ Valid } & 63.00 & 1 & 11.1 & 11.1 & 11.1 \\
\hline & 67.00 & 1 & 11.1 & 11.1 & 22.2 \\
\hline & 68.00 & 3 & 33.3 & 33.3 & 55.6 \\
\hline & 70.00 & 1 & 11.1 & 11.1 & 66.7 \\
\hline & 72.00 & 1 & 11.1 & 11.1 & 77.8 \\
\hline & 74.00 & 1 & 11.1 & 11.1 & 88.9 \\
\hline & 79.00 & 1 & 11.1 & 11.1 & 100.0 \\
\hline & Total & 9 & 100.0 & 100.0 & \\
\hline
\end{tabular}

Figures $(10,11,12$, and 13). Pie Bar Charts, for (Ife East, Ife South, Ife Central and Ife North).

PIE Chart 


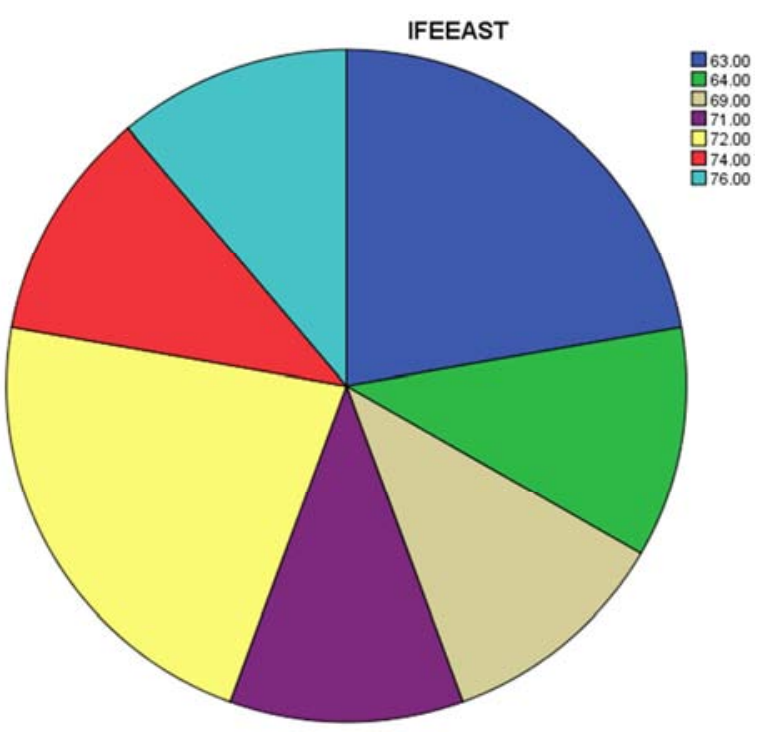

Figure 10. The Bar Chart of Ife East.

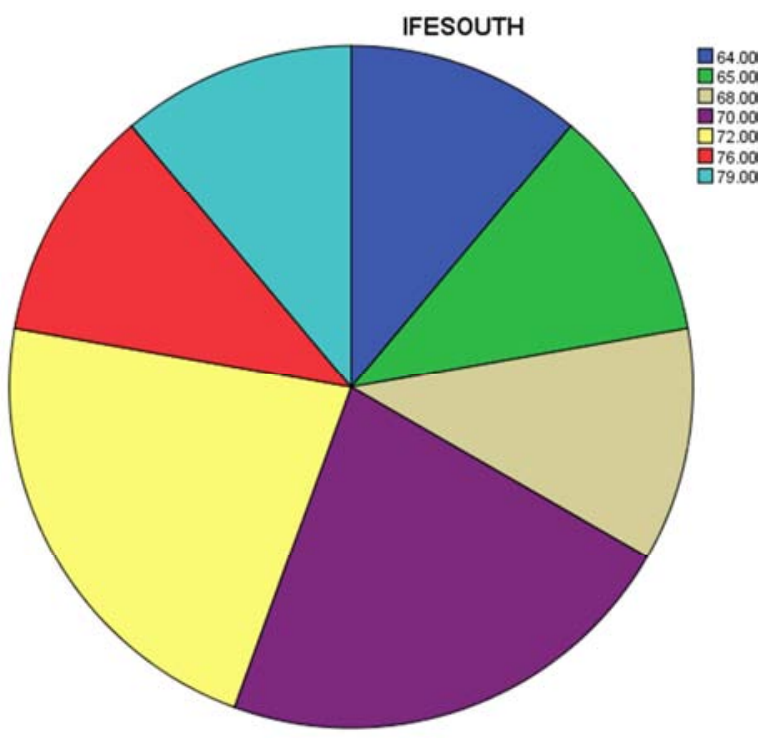

Figure 11. The Bar Chart of Ife South.

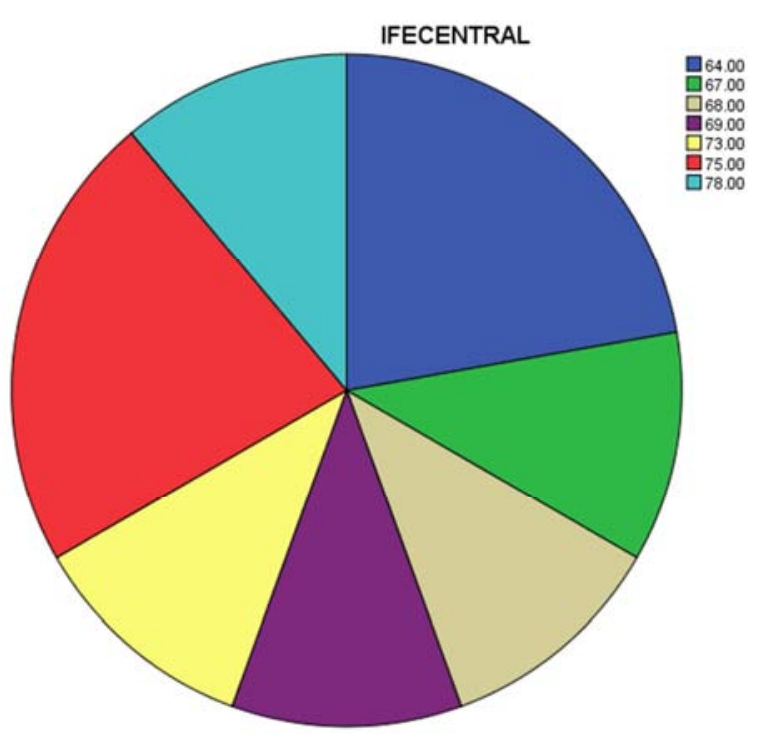

Figure 12. The Bar Chart of Ife Central.

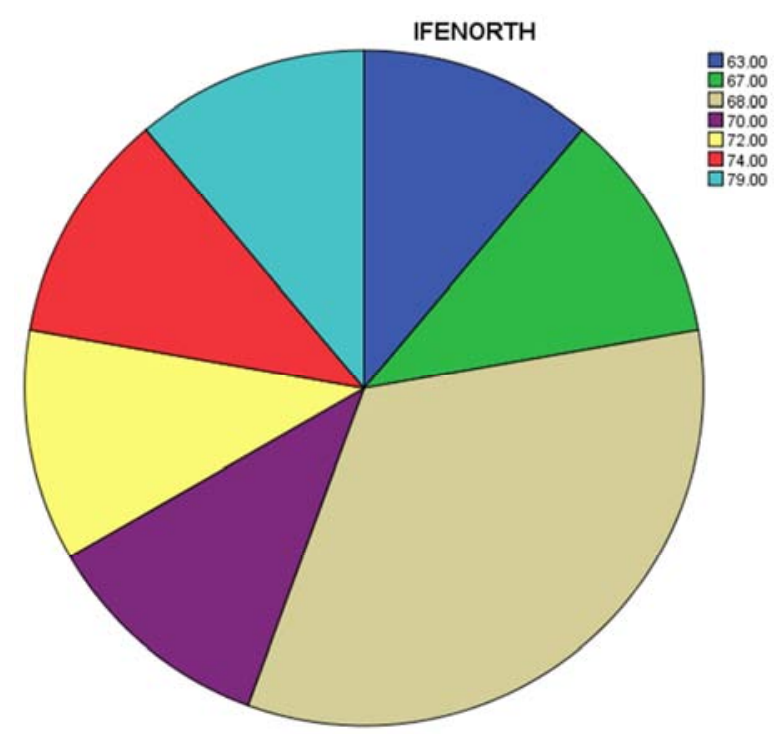

Figure 13. The Bar Chart of Ife North.

\section{Recommendations}

1. Nigerian Government should encourage plantain plantation, by given funds / loans to prospective investors 2 . Some of the rural areas roads in, Nigeria, are bad. Government should provide good motor-able roads to farmers in plantation areas with high concentration of plantain farm. 3. Government should provide electricity in rural areas for Farmers to enable them to stay longer in their farm for maximum increase in their plantain harvest Production. 4. Federal government should support the farmers by given enough assistance in terms of seedlings subsidy, so as to booth their production 5. Workshop at different intervals should be organized to farmers, so as to educate them in the uses of current farmer's equipments, to increase their plantain output production and eradicate plantain spoilage. 6. Government should organized Agricultural extension services to farmers by providing and bringing agricultural equipments closer to them, so as to reduce the cost of plantain harvest to the buyers. 7. For high Productivity and ultimate high investment, The Federal Government of Nigeria should encouraged plantain farmers to make research and seek expert opinion and advice for the latest productivity techniques to maximize profit. 8 . Government should erect large storage facilities at intervals for plantain farmers, to avoid losses and spoilage.

\section{Conclusion}

The following conclusions are made based on the findings of this study. Since plantain, as one of the major staple food in Nigeria, and plantain products is commonly used for making DODO (fried ripped pulp), IPEKERE well known as chip (fried un-ripped pulp), and as plantain flour. And also, it could be processed to food / food stuffs, such as break fast cereals, baby food (soy-musa), flour, chips and snacks food, couple with industrial product of plantain processing that 
includes: wine / beer, syrups, vinegar, biscuit, among others, the results of this study provide the empirical evidence that the importance of computerized analysis on spoilage of plantain, before harvest and carriage to market in Nigeria, had enhanced people's achievement in our society and in Nigeria at large. The society, therefore should use, the importance of computerized analysis on spoilage of plantain, before harvest and carriage to market in Nigeria's techniques, to argument peoples' maximal output in businesses, in order to attain minimum goal needed for everybody in the society.

\section{Acknowledgements}

The Author wishes to express his appreciations to all especially those whose papers that are shown in my references to provide the premise for this study, and Dr. /Chief Ramond Adedoyin, (The ATOBATELE, and MAYE of the Yoruba Kingdom); The Chancellor and Founder of Oduduwa University for providing the fund and space to carry out this research work / study.

\section{References}

[1] Aderinlewo E. O., 1982. Basic Secondary Science Book 1. Published by Evans Brothers Limited. Montague House, Russell square London WC1B5BX. Composition in 11 on 13 point century by Film type services Limited, Scarborough, North Yorkshire and Printed by William Clowes (Beccles) Limited, Beccles and London ISBN 0237505274. NPR 1137.

[2] Ashutosh Kar, 2011. Advanced Practical Chemistry. First Edition. Printed in India at Saras Graphics, Rai, Haryana. Typeset at Goswami Associates, Delhi. Publishing for one world. New Age International (P) Limited, Publishers. 4835/24, Ansari Road, Daryaganj, New Delhi. ISBN (0): 81224-1539-9. ISBN (13): 978-81-224-1539-1.

[3] C. M. A. Ademoroti, 2016. Environmental Chemistry \& Toxicology. Printed and Printed by: Folex Press Ltd., Ibadan. Typing and Manuscript: Mareh Prints and Consultancy. 47, Jona Akpaborie Street, BDPA, Ugbowo Estate, Benin. ISBN: 978-32413-1-1.

[4] Dr. Tilak Ram, 2013. Food Chemistry. Published in India by Random Publications. 4376-A/4B. Gall Murari Lai, Ansari Road, New Delhi-110002. Typesetting by: Friends Media, Delhi. Digitally Printed at: Replica Press Pvt. Ltd. ISBN 978$93-5111-032-3$

[5] Elservier, E. 2009. Guide to Protein Purification. $2^{\text {nd }}$ Edition. Academic Press. 525B street, suite 1900. San Diego, a 921014495, USA, 30 corporate Drive. Suite 400, Burlington, MA 01803, USA. 32 Jamestown Road, London. NW1 7BY, UK. ISBN. (hardback). ISBN: 978-0-12-374978-9 (paper back). ISSN: 0076-6879.

[6] Erelu, O. O., 2008. Cocoa for Health and Wealth. A Paper presented in a Fourth Cocoa Day Celebrationin Osun State between $22^{\text {nd }}-24^{\text {th }}$ April.

[7] Fan Y. Ding Z. Yang L. et al. A Preliminary Study on Bioactivity of Orange and Tangerine Pealextracts against Apulia and mites. Zhongguo Zhong Yao ZaZhi 1995 Jul: 20 (7): 397-8, 446. 1995. PMID: 13090.
[8] George Coulouris, Jean Dollimore and Tim Kindberg, 2011. Distributed Systems, Concepts and Design, $4^{\text {th }}$ Edition. Published by Dorling Kindersley [India] Pvt. Ltd. Licensees of Pearson Education in South Asia. Head Office: $7^{\text {th }}$ floor, Knowledge Bouleward. A-8 [A]. India Registered Office: 11 Community Centre, Panchsheel Park. New Delhi. India. Printed in India by Municipal Press Ltd. ISBN978-81-3171840-7. Authorized adaptation from the United Kingdom Edition, Entitled Distributed System Concepts and Design. Forth Edition, ISBN: 9780321263544 by Koulouris, George: Doll more, Jean; Kind berg, Tim; Published by Education, Ltd. Indian Subcontinent Adaptation Dorling Kindersley [India] Pvt. Ltd.

[9] Gordon M. Wardlaw, 2003. Contemporary Nutrition Issues and Insight. Fifth Edition. Published by Mc Graw-hill, a business unit of McGraw-Hill Companies, Inc., New York, NY 10020. ISBN: 0-07-286530-X. ISBN: 0-07-119903-X (15E). International Edition. ISBN: 0-07-118808-X.

[10] Honow R., Laube N. Schneider A, Kessier T. Hesser. Influence of grape fruit, Orange, and apple juice consumption on urinary variables and risk of crystallization. Br. Intr. Aug: 90 (2) 295-300.2003. PMID: 12908889.

[11] Jill Norman, 1997. The Classic Herb Cook Book. First published in Great Britain by Dorling Kindersley Limited. 9, Henrietta Street, London WC2E8PS. Reprint in 1997. A CIP for this book is available from the British Library. ISBN: 0751303232. Reproduced in Italy by Scanner Service SRL. Printed and bound in Italy by a Monadori, Veronica.

[12] John R. Holum, 1975. Experiments in General Organic and Biological Chemistry. A laboratory Manual, Forth Edition. New York. London. Sydney. Toronto. Printed in the United State of America. 10987654321.

[13] Kumar R., 1984. Insect Pest Control. First Published in Great Britain. Printed and bound in Great Britain by Athenaeum Press Ltd. Gates head British Library Cataloguing in Publication Data. ISBN 0713180838. Member of the Holder Headline Group. 338 Euston Road, London WW1 3BH.

[14] Melvin Calvin and J. A Bass ham1962. The Photosynthesis of Carbon Compounds. Library of Congress Catalogue Card Number: 62-10567. Manufactured in the United States of America. The Manuscripts was received November 15, 1961, and Published February 27, 1962. W. A. Benjamin, Inc. 2465 Broadway, New York 25, New York.

[15] Nyle C. Brandy, 1990. The nature and Properties of Soils. Printed in the United State of America by Mac Millian Publishing Company. Simon \& Schuster A. Viacon Company, Upper Saddle River, New Jersey, 074 p 58. ISBN 0-13-852444-0.

[16] Oduduwa University, 2016. General Inorganic Chemistry. Press Publication Ltd. Egbeda / Idimu Road, Egbeda, Lagos. ISBN: 978-978-50449-5-9.

[17] Oluyole K. A., 2005. Evaluation of the Economic of Post Harvest Processing of Cocoa in Cross River State, Nigeria. Journal of Agriculture, Forestry and the Social Sciences.

[18] O. P. Agarwal, 2014. Organic Chemistry, Natural Products Volume-1. Published by: Satyendra Rostogi, "mitra" for KRISHNA Prakasha media (P) Ltd. 11, Shivaji Road, India. Printed at Majmoon Press, Meerut. Typing: DEBUG CC. (The computer concern) Ghaziabad, ISBN: 978-81-8283556-6. 
[19] Rai H., 2004. Basic Industrial Biochemistry. Printed in India at Ram Pictograph, Delhi. Typeset at In-house. Publishing for one world. New Age International (P) limited. Publishers. Daryaganj, New Delhi. ISBN: 978-81-224-3404-0.295. C-1204-6261.

[20] Rama Rao Nadendla, 2016. Principles of Organic Medicinal Chemistry. Published by New Age International (P) Ltd., Publishers. ISBN: 81-224-1571-7. Printed in India at Ajit Printers, Delhi. Printers, Delhi.

[21] RapisardaP. Tomaino A. Lo Cascio R., et al. Antioxidant effectiveness as influenced by Phenol content of fresh orange juices. J, Agric Food Chem. 1999 Nov: 47 (11): 4718-23.1999. PMID: 13080 .

[22] S. K. Jain, 2001. Mineral Processing. For CBS Publishers and Distributors Pvt. Ltd. CBSP laza, Prahlad Street, Daryaganj, New Delhi-India. Ph: 23289259, 232668861, 23266867. ISBN: 81-239-0753-2.

[23] Tilak Wasan, 2015. Solid Waste Pollution and Health. Published at Arisari Road, 4383/4B, Darga Ganj. New Delhi110002 (India). ISBN: 978-93-5056-306-9. Discovery Publishing House PVT. Ltd. Printed at: Infinity Imaging Systems Delhi. 